\title{
Proximate Composition, Qualitative and Quantitative Phytochemical Screening of Aqeous Extract of Aspilia africana (Asteraceae) C.D Adams Leaves
}

\author{
Sherifat Ibidunni Adegbesan* \\ Department of Aquaculture and Fisheries Management, College of Environmental Resources Management, Nigeria
}

*Corresponding author: Sherifat Ibidunni Adegbesan, Department of Aquaculture and Fisheries Management, College of Environmental Resources Management, Federal University of Agriculture, Abeokuta (FUNAAB), P.M.B 2240, Abeokuta, Ogun State, Nigeria

\section{ARTICLE INFO}

Received: 幽 October 08, 2019

Published: 幽 October 18, 2019

Citation: Sherifat Ibidunni Adegbesan Proximate Composition, Qualitative and Quantitative Phytochemical Screening of Aqeous Extract of Aspilia africana (Asteraceae) C.D Adams Leaves. Biomed J Sci \& Tech Res 22(2)-2019. BJSTR. MS.ID.003711.

Keywords: Phytobiotics; A. Africana; Proximate composition; Phytochemical; Crude protein

\section{ABSTRACT}

Knowledge on phytobiotics for their nutritional value and usefulness is interestingly increasing. A study was conducted to investigate the proximate composition, quantitative and qualitative phytochemical constituents of Aspilia africana leaves. Fresh leaves of $A$. africana were obtained, identified and subjected to different processing methods for the proximate and phytochemical analysis. Standard methods of processing were used for the proximate and phytochemical analysis. Data obtained in this study were subjected to one way analysis of variance (ANOVA). The results of the proximate analysis indicated that $A$. africana contained high crude protein, $15.62 \pm 0.22 \%$, ash content, $16.17 \pm 0.19 \%$, crude fibre of $14.44 \pm 0.79 \%$ and a low fat content of $5.07 \pm 0.04 \%$. The phytochemical screening of tannin, alkaloid, saponins, sterols, terpenoids and glycosides revealed the presence of alkaloid in higher quantities $(8.22 \pm 0.40 \%)$, moderate quantity of tannin $(2.23 \pm 0.09 \%)$ and lowest quantity of terpenoids $(0.34 \pm 0.03 \%)$. The results of this study concluded that $A$. africana possessed some nutritional value and contained some active ingredients which makes it useful in human medicine as a result of its nutritional and medicinal value and its further strengthened the earlier works on the nutritional and medicinal values of $A$. africana.

\section{Introduction}

It was stated by [1] that for the isolation of beneficial compounds, different classes of plant species have been analysed with the help of upgraded Ayurvedic traditional methods and other advanced scientific techniques. Thus, authors such as [2] concluded that some of these plants are proven to be medicinal because they contain some active substance that bring about remedies to the cure of some peculiar diseases of man. Therefore, [3] reported that searches for substance with antimicrobial activity and healing activities are frequently considered interesting by some researchers since they are frequently used in medicine as remedies for many infectious diseases. Previous authors such as $[4,5]$ have reported that plant extracts have been reported by various researchers to favor various activities like anti-stress, growth promotion, and appetite stimulation, enhancement of tonicity and immunostimulation, maturation of culture species, aphrodisiac and anti-pathogen properties in fish and shrimp aquaculture. These functions performed by these plants extracts are traced to the active principles such as alkaloids, terpenoids, tannins, saponins, glycosides, flavonoids, phenolics, steroids or essential oils that are inherent in them.

A. africana (Asteraceae); (Pers) C.D. Adams (plate 1), a perennial herb varying in height from $60 \mathrm{~cm}$ to about $1.5 \mathrm{~m}$ depending on rainfall [6]. Authors like [7,8] also defined it as a common weed of field crops in West Africa found in fallow land, especially in the forest zone. Scientific reports of $[9,10]$ suggested that different crude extracts of the plant contain specific bioactive constituents that could have varied effects on its biological activities. A report of [11] on the evaluation of the potentials of $A$. africana in wound care showed that the leaf extract and fractions exhibited haemostatic, antimicrobial and wound healing activities suggesting that the 
constituents of the leaves may play a useful role in wound care. $[12,13]$ both reported that phytochemical analysis of the extract and fractions indicated the presence of typical plant constituents such as alkaloids, saponins, sterols, terpenoids, carbohydrates, glycosides and tannins. The phytochemical analysis and subsequent quantification of A. africana revealed the presence of high amount of some bioactive compounds; saponins, tannins, alkaloids, flavonoids, terpenoid and phenol, but little amount of steroids, phylobatannin and cardiac glycoside [9].

The work of [11] concluded that these metabolites are usually responsible for the biological and pharmacological activities of these medicinal plants. The result of preliminary phytochemical analysis of the petals of $A$. africana in the study of [14] showed the presence of saponins, tannins, flavonoids and cardiac glycosides. Flavonoids exhibit a broad range of biological activity such as antimicrobial, anticancer, anti-allergic as well as anti-tumour properties. Also, flavonoids are potent water-soluble antioxidants and free radical scavengers, which prevent oxidative cell damage, have strong anticancer activity $[15,16]$ is of opinion that flavonoid in the plant petal is an important component of a normal diet, and has been suggested that flavonoid-rich foods may limit neurodegeneration and prevent or reverse normal or abnormal deterioration in cognitive performance. Furthermore, a report of $[17,18]$ on saponins which were present in abundant quantity in A. africana petal has anti-inflammatory, anti-yeast, anti-fungal, anti-tumours, anti-parasitic and antiviral activities that confirms its usefulness in trado-medicinal practices.

In addition, [19] stated that it has the property of precipitating and coagulating red blood cells and some characteristics of saponins include formation of foams in aqueous solutions, hemolytic activity, cholesterol binding properties and bitterness). [14] stated that these properties bestow high medicinal activities on the extracts from $A$. africana. Another important metabolite and active compound in $A$. africana is tannins which have astringent and detergent properties were also present in trace quantity in the plant petal, and this could be responsible for their anti-fungal activity when used against diarrhoea and malaria. This coincides with reported works of [20-23] confirmed the nutritional and medicinal importance of $A$. africana leaves which has been established and to obtain effective performance and feed efficiency, diet should be formulated to meet the needs of animal particularly age or stage of production. It is commonly used to feed livestock particularly sheep and goats [24]. Hence this study entails the investigation of aqueous extract of $A$. africana leaves for its nutritional and phytochemical constituents and importance.

\section{Materials and Methods}

\section{Collection and Harvesting of the Phytobiotic}

Fresh young leaves of $A$. Africana was harvested separately within the premises of Federal University of Agriculture, Abeokuta, and Ogun State, Nigeria. The plants was authenticated in the
Department of Forestry and Wildlife where a voucher specimen was maintained for the plant (A. africana ID No: UAHA/08.180001). The leaves of the phytobiotic was obtained by harvesting whole plant (stem and leaves) above a $3 \mathrm{~cm}$ stubble height within the mid vegetative to early flowering stage of development as described by [25]. Thereafter, the leaves was hand-plucked from stems and separately put directly into jute-bag. Fresh samples of the leaves were taken to the laboratories for the proximate and phytochemical (quantitative and quantitative) analysis.

\section{Proximate (Nutritional) Analysis of the Phytobiotic}

After sample collection and identification, 200g of fresh $A$. africana leaves were weighed using a weighing scale (mettler Toledo FB602), the leaves were air-dried and grinded to fine powder using an electric blender ((Century, CB-8231-M). Proximate analysis of moisture content, crude fibre, crude protein content, carbohydrate and fat content were carried out following procedure as described by [26] in SOAR research and diagnostic laboratory. Abeokuta, Ogun state, affiliated to Federal University of Agriculture, Abeokuta, Ogun state.

\section{Phytochemical Screening of Aqueous Extract of the Phytobiotic}

$80 \mathrm{~g}$ of the plant powder were weighed weighing balance (mettler Toledo FB602) and homogenized in a clean electric blender containing $80 \mathrm{ml}$ sterile distilled water following procedures as described by [27]. The homogenates (amber green solution) were shaken for $1 \mathrm{hr}$ in a rotary flask and after 72 hours, filtered into separate sterile containers using a funnel containing sterile cotton wood and later with Whatman No. 1 filter paper. The liquid filtrates were transferred into sterile MacCartney bottles and stored in the refrigerator. The qualitative and quantitative phytochemical screening of leaves paste of $A$. africana was carried out following procedures as described by [28-30] in TETRA "A" analytical and diagnostic laboratory affiliated to Federal University of Agriculture, Abeokuta, Ogun state.

\section{Results and Discusssion}

\section{Proximate Composition (\%) of $\boldsymbol{A}$. africana Leaves}

The proximate composition of $A$. africana leaves is presented in (Table 1). Ash content is the highest (16.17\%) in A. africana leaves also with a crude protein content of $15.62 \%$ and ether extract of $5.07 \%$. The leaves has a high moisture content of $9.65 \%$ and rich in fibre content of $14.4 \%$. The nutritional analysis of the leaves in this present study showed that crude protein and crude fibre are high in A. africana. This suggest that the plant is an important source of plant proteins likewise the high fibre contents in these leaves could help to maintain gastro-intestinal tract health [31]. Also, protein, containing nitrogen in any food sample is used as an indication of protein level usually termed as crude protein which is different from true protein [32]. In this study, protein content of $15.62 \%$ in $A$. africana leaves indicated that $A$. africana leaves are rich in protein. 
Also, high crude protein in this leaves is in line with the work of $[23,33]$ who made similar discovery. The high fibre content in $A$. africana leaves is in agreement with the work of [14] who made similar findings in A. africana. This implies that the plant has more woody materials as stated by [34] that fibre determination is the criteria for judging purity of herbal crude drugs. The carbohydrate content of $61.64 \%$ is comparable with the work of [35]. This is an indication that the plant is a good source of energy for both human and animal use. Carbohydrate as it is present in A. africana in this present study corroborated with the work of $[14,24]$ who reported the presence of carbohydrate in A. Africana leaves.

Table 1: Proximate compositions of Aspilia africana leaves (\% Dry weight).

\begin{tabular}{|c|c|}
\hline Proximate Components & Amount (\%) \\
\hline Ash & $16.17 \pm 0.19$ \\
\hline Ether extract & $5.07 \pm 0.04$ \\
\hline Crude Protein & $15.62 \pm 0.22$ \\
\hline Moisture Content & $9.65 \pm 0.24$ \\
\hline Crude Fibre & $14.44 \pm 0.79$ \\
\hline Nitrogen free extract & $39.06 \pm 0.89$ \\
\hline Carbohydrate & $61.64 \pm 0.74$ \\
\hline
\end{tabular}

Qualitative and Quantitative Phytochemical Analysis of

\section{A. africana Leaves}

Table 2: Qualitative Profile of Phytochemicals Found in Aspilia africana leaves.

\begin{tabular}{|c|c|}
\hline Phytochemical & Status \\
\hline Alkaloid & ++ \\
\hline Saponin & ++ \\
\hline Flavonoid & - \\
\hline Sterols & + \\
\hline Terpenoid & + \\
\hline Cardiac glycoside & + \\
\hline Tannin & ++ \\
\hline
\end{tabular}

Qualitative Profile of Phytochemicals Found in Aspilia africana leaves.

The qualitative phytochemicals found in A. africana leaves is shown in (Table 2). Alkaloid is highly present followed by saponins and tannins which are moderately present, while sterols, terpenoids and glycosides are slightly present. The quantitative phytochemicals found in A. africana leaves is shown in (Table 3). A. africana leaves contained the highest crude yield of carbohydrate $(61.64 \pm 0.74 \%)$, followed by alkaloid with the yield of $8.22 \pm$ $0.40 \%$ and saponin with the yield of $4.20 \pm 0.05 \%$ and terpenoid having the lowest yield of $0.34 \pm 0.03 \%$. The results of quantitative and qualitative phytochemical analysis (aqueous extract) in the leaves of $A$. africana revealed the presence of alkaloid in moderate quantities. Alkaloids possess high antimicrobial activities by disrupting the function of cytoplasm membrane causing the leakage of some beneficial metabolite and inactivated bacterial enzymatic system [36]. This result was corroborated by the work of [24] who revealed the presence of alkaloid in moderate quantity in A. africana. Saponins which are present in abundant quantities in A. africana leaves possess some anti-inflamtory and anti-microbial activities as described by some researchers $[17,18]$.

Table 3: Quantitative Profile of Phytochemicals Found in Aspilia africana leaves.

\begin{tabular}{|c|c|}
\hline Phytochemical & Amount (\%) \\
\hline Alkaloid & $8.22 \pm 0.40$ \\
\hline Saponin & $4.20 \pm 0.05$ \\
\hline Sterols & $0.40 \pm 0.01$ \\
\hline Terpenoid & $0.34 \pm 0.03$ \\
\hline Glycoside & $1.18 \pm 0.04$ \\
\hline Tannin & $2.23 \pm 0.09$ \\
\hline Carbohydrate & $61.64 \pm 0.74$ \\
\hline
\end{tabular}

It also has the ability of precipitation and coagulation of red blood cells and thus serving as a haemolytic agent [19]. This observation is in agreement with the reports of [14,24,37] who revealed the presence of saponin in A. africana. The absence of flavonoid in A. africana as observed in this study corroborated with the work of [24]. Steroid and terpenoid which are known to inhibit microbial growth by destroying the plasma membrane, thus leaking the cell cytoplasm causing cellular death and therefore reducing pathogenic diseases [38] is present in A. africana leaves. This present investigation also revealed the preence of tannin in moderate quantities in the leaves of A. africana. The presence of tannins in the plant indicated that these plants can act as an astringent and this might suggest that $A$. africana leaves could have anti-viral and anti-bacteria properties. This corroborates the reports of [14] who recorded the presence of tannin in A. africana leaves. This report revealed the presence of cardiac glycoside in small quantity in A. africana leaves which is in agreement with the works of $[14,39]$ who discovered similar findings on A. africana. The presence of cardiac glycoside in this plant suggest that the plant could be of medical importance and the bases of use in ethno medicines

\section{Conclusion}

This present study elucidated the importance of the nutritional compostion and the quantitative and qualitative phytochemicals constituents inherent in A. africana leaves which confirmed that the leaves is a potent medicinal plant as a result of the important active phyto-compounds present in the leaves and as such, this study has detailed its potential for use in herbal medicine. Also. A. africana leaves could also be used as an anti-microbial due to the important phytochemicals such as steroid, alkaloid and terpenoid present in the leaves. Furthermore, the high protein and fibre contents present in the A. africana leaves indicated that plant could serve as an important forage material for animal consumption. 


\section{References}

1. Bawankar R, Singh P, Subramanaian B (2014) Bioactive compounds and medicinal properties of Aloe vera L.: An Update. Journal of Plant Sciences 2(3): 102-107.

2. Sliva Junior AA, Vizotto VJ, Giorgi E, Macedo SG, Marques LF, et al. (1994) Plants medicinals, caracterizacao e cultivo EPAGRI. Bol Tecnico Florianopolis 68: 1-71.

3. Odunbaku OA, Ilusanya OA (2008) Antibacterial Activity of the Ethanolic and Methanolic Leaf Extracts of Some Tropical Plants on Some Human Pathogenic Microbes. Research Journal of Agriculture and Biological Sciences 4(5): 373-376.

4. Chakraborty SB, Hancz C (2011) Application of phytochemicals as immunostimulant, antipathogenic and antistress agents in finfish culture. Reviews in Aquaculture 3: 103-119.

5. Citarasu T (2010) Herbal biomedicines: a new opportunity for aquaculture industry. Aquaculture International 18: 403-414.

6. Akobundu IO (1987) Weed Science in the Tropics: Principles and practice. Chichester, John Wiley and sons. United Kingdom pp. 522.

7. Burkill HM (1985) The Useful Plants of West Tropical Africa. Royal Botanical Garden 40(2): 446-447.

8. Hutchinson J (1962) Flora of West Tropical Africa, Mill Bank, London: Crown Agents for Overseas Government and Administration 119.

9. Kuiate JR, Amvam Zollo PH, Lamaty G, Menut C, Bessiere JM, et al. (1999) Composition of the Essential oils from the leaves of two varieties of Aspilia africana (Pers). Flavour and Fragrance Journal 14(3): 167-169.

10. Okoli CO, Akah PA, Nwafor SV, Anisiobi AL, Ibegbunam IN, et al. (2007) Anti-inflammatory activity of hexane leaf extract of Aspilia africana CD Adams. Journal of Ethnopharmacology 109(2): 219-225.

11. Obuzor GU, Nkom JN (2010) Fatty Acid Composition of Aspilia africana (Nigerian). International Archive of Plant Sciences Technology 1(2): 1319.

12. Okoli CO, Akah PA, Nwafor SV, Anisiobi AL, Ibegbunam IN, et al. (2007) Anti-inflammatory activity of hexane leaf extract of Aspilia africana CD Adams. Journal of Ethnopharmacology 109(2): 219-225

13. Olonishakin A, Adei Edeh PO, Idok R (2010) Oil quality characteristics of Cultivars sinnensis and Citrullus lanatus seed oils. J Chem Soc Nig 35(1): 28-32.

14. Essiett U, Akpan UI (2013) Comparative Phytochemical and Physicochemical Properties of Aspilia africana (Pers) C. D. Adams and Tithonia diversifolia (Hemsl) A. Gray Petals as a Scientific Backing to Their Tradomedicinal Potentials. International Journal of Modern Biology and Medicine 3(2): 88-100.

15. Pietta PG (2000) Flavonoids as Antioxidants. Journal of Natural Production 63(7): 1035-1042.

16. Spencer J (2010) The impact of fruit flavonoids on memory and cognition. British Journal of Nutrition 104(3): 40-47.

17. Sofowora AN (2008) A medicinal plants and traditional medicine in West Africa, 3rd edition. John Wiley and Sons Ltd. New York, USA, pp. 200-203.

18. Sparg SG, Light ME, Stadan JV (2004) Biological Activities and Distribution of Plant Saponins. Journal of Ethnopharmacology 94: 219243.

19. Okwu DE (2004) Phytochemicals and vitamins content of indigenous species of southeastern Nigeria. Journal of Sustainable Agricultural Environment 6(1): 30-37.
20. Bouquet MN, Harvey VL, Debray AH (2008) Mechanism of Pain in nonmalignant diseases. Curopin Support Pallat Care 2(2): 133-228.

21. Trease GE, Evans WE (2002) Pharmacognosy. (15 ${ }^{\text {th }}$ Edition) W.B. Saunders Company Limited, London 585.

22. Bruneton J (1999) Pharmacognosy, Phytochemistry, Medicinal Plants. Second Edn, Lavoister publishers, France pp. 1-1119.

23. Adedeji OA, Ajibade MO, Folayan JA (2015) Effect of Aspillia africana leaves on reproduction of rabbit. Journal of Development and Agricultural Economics 7(6): 231-236.

24. Agbor RB, Ekpo IA, Ekanem BE (2012) Antimicrobial Properties and Nutritional Composition of Aspilia africana C.D. Adams, International Journal of Applied Science and Technology 2: 7-12

25. Kalu BA, Njike MC, Ikurior SA (1986) Evaluating the potential of Tridax procumbens for livestock feed. II. Seasonal changes in chemical composition. Nigerian Journal of Animal Production 13: 23-28.

26. (2011) AOAC Association of International Official Analytic Chemists, AOAC International, 18th edn, Arlington, Virginia.

27. Sofowora AN (1982) A medicinal plants and traditional medicine in West Africa, $3^{\text {rd }}$ (edn.). John Wiley and Sons Ltd. New York, USA pp. 200-203.

28. Harborne JB (1973) Phytochemical methods. Chapman and Hall Ltd. London pp. 49-188.

29. Trease GE, Evans WC (1989) Pharmacognsy. $11^{\text {th }}$ edn. Brailliar Tiridel Can. Macmillian publishers London, England.

30. Sofowara A (1993) Medicinal plants and Traditional medicine in Africa. Spectrum Books Ltd, Ibadan, Nigeria pp. 289.

31. African Pharmacopoeia (1986) Dau Istrc Scientific Publications Lagos, Nigeria pp. 140-150.

32. Okon EU (2005) Handbook of basic food and beverage analysis. Etovin publ, AKS, Nigeria p. 53-70.

33. Ojebiyi O0, Shittu MD, Oladunjoye IO, Omotola OB, Olaniyi SA, et al. (2013) Haematology, carcass and relative organ height of growing rabbits on skip-a-day concentrate feeding regime. International Journal of Applied Agricultural and Apicultural research 9: 167-174.

34. Agarwal A (2005) Critical issues in Quality control of Herbal products. Pharma Times 37(6): 9-11.

35. Javid H, Abdul LK, Najeeb UR, Zainullah FK, Sejed T, et al. (2009) Proximate and Nutrient Investigations of Selected Medicinal Plants Species of Pakistan. Pakistan Journal of Nutrition 8: 620-624.

36. Harlina PA, Subrajitino E, Nursyam H (2013) The Identification of Chemical Compound and Antibacterial Activity Test of Kopasanda (Chromolaena odorata L.) Leaf Extract Against Vibriosis-Causing Vibrio harveyi (MR 275 Rif) on Tiger Shrimp. Aquatic Science and Technology 1(2): 2168-9148

37. Edeoga HO, Okwu DE, Mbaebe BO (2005) Phytochemical constituents of some Nigerian medicinal plant. African Journal of Biotechnology 4(7): 685-688.

38. Putra INK (2007) Study Power Antimicrobial Preservatives Plant Extract Multiple Materials destroyer Nira nira against Microbes and Gynecology Actively compounds. (Unpublished Doctoral Dissertation). University of Brawijaya, Malang.

39. Ibrahim MSA, Mona HA, Mohammed A (2008) Zooplankton as live food for fry and fingerlings of Nile Tilapia (Oreochromis niloticus) and Catfish Clarias gariepinus in Concrete ponds. Central Laboratory for Aquaculture Research (CLAR), Abbassa, Sharkia, Egypt. $8^{\text {th }}$ International Symposium on Tilapia in Aquaculture: 757-769. 


\section{ISSN: 2574-1241}

DOI: 10.26717/BJSTR.2019.22.003711

Sherifat Ibidunni Adegbesan. Biomed J Sci \& Tech Res

(C) (i) This work is licensed under Creative

Submission Link: https://biomedres.us/submit-manuscript.php

$\begin{array}{ll}\text { BIOMEDICAL } & \text { Assets of Publishing with us } \\ \text { RESEARCHES } & \text { - Global archiving of articles } \\ \text { - Immediate, unrestricted online access }\end{array}$

